\title{
Influence of Meteorological Parameters on Occurrence and Composition of Fungal Spores in Guava Orchard at Nasik
}

\author{
Shinde H. P. \\ Department of Botany, K.V.N. Naik College, India \\ Received March 15, 2020; Revised April 25, 2020; Accepted May 3, 2020
}

Copyright $\bigcirc 2020$ by authors, all rights reserved. Authors agree that this article remains permanently open access under the terms of the Creative Commons Attribution License 4.0 International License

\begin{abstract}
The present study deals with an aeromycological sampling, monitoring and analysis of fungal spore incidence over selected guava orchard in Nasik city. It involved monitoring on occurrence of some important air borne fungal spores, and their changing composition due to fluctuating weather conditions. The study was conducted by using volumetric Tilak air sampler during a period of January 2018 to December 2018; on Guava (Psidium guajava Linn.) fruit plant to trace pathogenic fungal mycoflora associated with the changing climatic conditions; responsible for different diseases. The meteorological parameters like temperature, relative humidity, wind speed and precipitation, in that order of importance, significantly influence the composition of airborne fungal spores. Variations and daily fluctuations in these weather conditions may provide a stimulus to the sporadic outbreaks of certain pathogenic airborne fungal spores that further cause a plant disease. An attempt was made to assess airborne fungal spore distribution patterns in relation to meteorological variables during the period of study. Also, it was observed that, the occurrence of fungal spores was in correlation with the weather changes, field operation, plant growth and disease incidence on the crop. The major diseases caused due to an outbreak of fungal spores on guava orchard were found to be stimulated by moderate precipitation and rapid fluctuations associated with high percentage of humidity.
\end{abstract}

Keywords Meteorological Parameters, Fungal Spores, Nasik

\section{Introduction}

Variation in the weather conditions may provide a stimulus to the sporadic outbreaks of certain pathogenic airborne fungal spores that further cause a plant disease.
The diseases to which a plant may become susceptible is influenced by a local climatic condition of a particular region which is determining its susceptibility and quality that makes the crop commercially profitable. Whether or not a plant disease is significant; in crop production; often depends upon how the local or seasonal climatic conditions meet the requirements for the development and spread of the pathogen. The relation between the disease development and weather; is the basis on which, occurrence of disease can be predicted. The meteorological parameters like temperature, relative humidity, wind speed and precipitation, in that order of importance, significantly influence the composition of airborne fungal spores. Boddy et al., (2014); Grinn-Gofron et al. (2018).

It is well known that the presence of fungi, formation and dispersion of their propagating structures are responsible for disease incidence on variety of agricultural crops. This is significantly influenced and interacted by abiotic factors and meteorological parameters. Tilak et al. (2009). Many of the fungal spores are endowed with unique structures and capacity to survive under unfavourable environmental conditions and these probably account for their predominance in the air. Mishra and Deshmukh (2009). The major diseases caused due to an outbreak of fungal spores on guava orchard were found to be stimulated by moderate precipitation and rapid fluctuations associated with high percentage of humidity. The fungal spores which are always present in an air tend to fluctuate in terms of their concentration, composition and periodicity; due to the continuous complex type of interactions between biotic and abiotic factors of an environment such as topography, soil and climatic conditions, anthropogenic activities etc. The occurrence of the fungal spores in terms of their production, release, dispersal and pathogenicity is mainly influenced by meteorological factors. However; not a single but 
combination of two or more factors are generally responsible for the complex and dynamic behaviour of the fungal spores. Azcón-Bieito and Talón (2000). The colonization of any fungi infecting fruit products, as well as the production of mycotoxins, is dependent on an array of factors that are of intrinsic or extrinsic nature. Sardella et al. (2016).

The relationship between fungal spore concentration and the prevalent climatic conditions could be ascertained by the aerobiological studies. However; proper analysis of aerobiological data thus obtained, is required for getting more reliable view of fungal spore occurrence in the air. Grinn-Gofron and Bosiacka (2015).

As the agro climatic conditions in Nasik are quite pleasant; the cultivation of horticultural plants is gaining importance. Guava (Psidium guajava Linn. Family Myrtaceae) is an important fruit crop of after grapes and is extensively cultivated fruit plant in Nasik region. Also; it is hardy crop, can be cultivated successfully even in neglected soils \& it is attacked by large number of pathogens mainly fungi. Gupta et al. (2010). Guava fruit contains phenolic compounds that are helpful for skin and diseases like cancer, it possesses anti-viral, anti-inflammatory activities Naseer and Hussain et al. (2018). Weather conditions may cause rapid production, germination, dispersal and spread of infection by the fungal spores. Surendranathan (2005); Zhu (2006). Though the effect of meteorological factors on fungal spores is an extensively studied phenomenon; little is known about the field epidemiology of guava diseases and importance of early disease detection in disease management. Fischer et al. (2017).

\section{Materials and Methods}

\subsection{Study Area}

The Nasik city is one of the megacities; also known as grape city or wine capital of Maharashtra, located in North part of Maharashtra. Though the Nasik is popularly known for its onion and tomato production; Guava is an emerging important horticultural crop of Nasik and has a tremendous scope for area expansion in guava cultivation, processing and marketing after grapes and pomegranates. The guava orchard situated at gangapur region which is about $10 \mathrm{~km}$ away from Nasik city; was selected for the trapping of fungal spores by operating continuously Tilak air sampler. Tilak and Kulkarni; (1970).

The Tilak air sampler was installed on iron made stand at a constant height of $4^{1 / 2}$ feet from the ground. It is an electrically operated device (AC-230V) consists of a cubical tin box of 10.4 " $\mathrm{x} 10.4$ " $\mathrm{x} 8$ " dimension with the closing lid at the top. Air is sucked in through the orifice projecting tube at the rate of 5 litres/minutes. As the air rushes in, it impinges on the transparent cellotape of the rotating drum coated with the thin layer of petroleum jelly and thus entraps the bioparticles including fungal spores from the air. The air is sucked through the tube with the help of small fan having three prongs and fixed in the circular opening in the cover of air sampler, so as to force the air out the collection chamber causing a negative pressure. Air was sampled at the rate of 5 litres/minute and the transparent cellotape coated with white petroleum jelly that was changed every 8 days. The mounting of the cello tape having catches of spores; is done in glycerine jelly which was prepared separately. The preparation of permanent microscopic slides and their scanning by using compound microscope as well as binocular research microscope; was done regularly on weekly basis. The counting of fungal spores and other bioparticles was done by Hirst short transverse method (1952) and identification of fungal spores; was based on microscopic diagnostic features, reference slides \& available literature. The meteorological data such as daily temperature, relative humidity, average rainfall, wind velocity etc. were obtained from the Hydrology unit, Maharashtra Engineering Research Institute, (M.E.R.I.) Nasik.

The data of trapped fungal spores was compiled and their final concentrations expressed in terms of spores $\mathrm{m}^{-3}$ of the air sampled. Also, the data was analysed statistically by applying two-way ANOVA test (significance at the 0.05) using windows Microsoft version 19, 2014 with respect to the changing climatic conditions during three seasons of study period.

\section{Results and Discussion}

Low temperature and a slight rainfall with high humidity favours the occurrence of most of the fungal spores. Mohture \& Koprenwar; (2015). A change in temperature may influence the colonization and growth of fungi directly through the physiology of individual organisms, or indirectly through physiological effects on their host plants or substrates. Charlotte Sindt et al. (2016). Local meteorological conditions have strong effects on temporal and spatial variations in concentration of fungal spores. Kumar and Attri (2016). Also, it is well established that the air is always carrying many bioparticles, especially fungal spores however; the concentration or fungal spore load may change according to the local climate, vegetation and anthropogenic activities.

During the present studies; the spores belonging to Deuteromycotina dominated among all fungal spore groups with 12 spore types followed by Ascomycotina with 08 spore types, Phycomycotina with 04 spore types and Basidiomycotina with 02 spore types. (Table 1). The Deuteromycotina contributed maximum to the total airspora during three seasons with the average contribution of $9.79 \%$ \& $82 \%$ (monsoon) $4.85 \%$ \& $67 \%$ (winter) and $3.66 \% \quad \& \quad 63 \%$ (summer) whereas; Basidiomycotina contributed least i.e. $0.65 \%$ \& $05 \%$ (monsoon), $11 \%$ (winter $0.83 \%$ and summer $0.61 \%$ ) 
similarly; Ascomycotina contributed maximum of 1.01\% $\& 18 \%$ (summer), $0.98 \% \& 13 \%$ (winter) and $1.02 \% \& 09 \%$ (monsoon). (Table $2 \&$ Table 3) (Fig. 2). 
Table 1. Average monthly contribution of spore types (spore $\mathrm{m}^{-3}$ ) during the period of investigation ( $1^{\text {st }} \mathrm{Jan} .2018$ to $31^{\text {st }}$ Dec. 2018)

\begin{tabular}{|c|c|c|c|c|c|c|c|c|c|c|c|c|c|c|c|c|}
\hline $\begin{array}{l}\text { Sr } \\
\text { No }\end{array}$ & Spore Type & January & February & March & April & May & June & July & August & September & October & November & December & Average & $\begin{array}{l}\text { Total no. } \\
\text { of spores }\end{array}$ & $\begin{array}{c}\text { Percent } \\
\text { Contrib- } \\
\text { ution } \\
(\%) \\
\end{array}$ \\
\hline & ASCOMYCOTINA & & & & & & & & & & & & & & & \\
\hline 1 & $\begin{array}{l}\text { Botryosphaeria Ces de } \\
\text { Not. }\end{array}$ & 1132 & 1061 & 872 & 741 & 535 & 421 & 695 & 526 & 799 & 565 & 785 & 911 & 753.58 & 9043 & 2.53 \\
\hline 2 & Pringshemia Schults. & 921 & 833 & 621 & 513 & 314 & 594 & 826 & 655 & 742 & 530 & 622 & 741 & 659.33 & 7912 & 2.21 \\
\hline 3 & Hypoxylon Bull ex. Fr. & 321 & 413 & 290 & 112 & 132 & 277 & 435 & 459 & 510 & 156 & 342 & 367 & 317.83 & 3814 & 1.07 \\
\hline 4 & Didymosphaeria Fuck. & 1243 & 1197 & 791 & 812 & 572 & 832 & 1112 & 945 & 973 & 652 & 876 & 1154 & 929.92 & 11159 & 3.12 \\
\hline 5 & Lacanidion Endl. & 324 & 361 & 223 & 216 & 189 & 310 & 342 & 342 & 495 & 289 & 381 & 368 & 320.00 & 3840 & 1.07 \\
\hline 6 & Lophiostoma Ces de Not. & 122 & 109 & 77 & 71 & 67 & 95 & 117 & 127 & 102 & 87 & 108 & 134 & 101.33 & 1216 & 0.34 \\
\hline 7. & Sporormia de Not. & 142 & 256 & 270 & 587 & 623 & 456 & 138 & 243 & 205 & 67 & 43 & 129 & 263.25 & 3159 & 0.88 \\
\hline \multirow[t]{2}{*}{8.} & Pleospora Rabh. & 198 & 267 & 356 & 510 & 598 & 411 & 112 & 149 & 105 & 56 & 34 & 123 & 243.25 & 2919 & 0.82 \\
\hline & BASIDIOMYCOTINA & & & & & & & & & & & & & & & \\
\hline 9. & Basidiospores & 72 & 91 & 88 & 56 & 72 & 352 & 445 & 465 & 394 & 426 & 416 & 118 & 249.58 & 2995 & 0.84 \\
\hline \multirow[t]{2}{*}{10} & Smuts & 3280 & 2834 & 1721 & 1634 & 2321 & 1692 & 2587 & 2132 & 1320 & 2450 & 2720 & 2340 & 2252.58 & 27031 & 7.55 \\
\hline & DEUTEROMYCOTINA & & & & & & & & & & & & & & & \\
\hline 11 & Alternaria Nees. & 789 & 1160 & 840 & 1551 & 1670 & 6570 & 7420 & 7213 & 6138 & 1729 & 1268 & 989 & 3111.42 & 37337 & 10.43 \\
\hline 12 & $\begin{array}{l}\text { Aspergillus Micheli ex } \\
\text { Link. }\end{array}$ & 156 & 176 & 160 & 232 & 136 & 1210 & 1456 & 1389 & 1612 & 687 & 834 & 193 & 686.75 & 8241 & 2.30 \\
\hline 13 & Cercospora Fr. & 514 & 412 & 452 & 1253 & 1574 & 5872 & 6268 & 5983 & 6032 & 1343 & 889 & 657 & 2604.08 & 31249 & 8.73 \\
\hline 14 & Cladosporium Link. & 3542 & 3271 & 2621 & 2232 & 1723 & 1811 & 1432 & 1643 & 1430 & 2123 & 2630 & 2944 & 2283.50 & 27402 & 7.65 \\
\hline 15 & Colletotrichum Corda & 1124 & 1235 & 965 & 933 & 873 & 4897 & 5912 & 6578 & 7867 & 3245 & 2987 & 1897 & 3209.42 & 38513 & 10.76 \\
\hline 16 & $\begin{array}{c}\text { Corynospora Berk and } \\
\text { Br. }\end{array}$ & 521 & 692 & 447 & 684 & 801 & 858 & 851 & 638 & 424 & 693 & 652 & 801 & 671.83 & 8062 & 2.25 \\
\hline 17 & Curvularia Boed. & 2514 & 2636 & 1459 & 1291 & 1223 & 3268 & 3530 & 2611 & 2267 & 2129 & 2132 & 2532 & 2299.33 & 27592 & 7.71 \\
\hline 18 & $\begin{array}{l}\text { Epicoccum Link } \\
\text { ex.Wallr. }\end{array}$ & 512 & 544 & 142 & 158 & 225 & 138 & 172 & 96 & 118 & 141 & 286 & 484 & 251.33 & 3016 & 0.84 \\
\hline 19 & Fusarium Link. & 3155 & 3243 & 2544 & 1123 & 1988 & 3869 & 3698 & 3723 & 2988 & 1961 & 2876 & 3110 & 2856.50 & 34278 & 9.57 \\
\hline 20 & $\begin{array}{l}\text { Helminthosporium } \\
\text { Link.ex Fr. }\end{array}$ & 1223 & 989 & 979 & 1113 & 1067 & 2234 & 2476 & 2832 & 2489 & 1357 & 1117 & 992 & 1572.33 & 18868 & 5.27 \\
\hline 21 & Nigrospora Zimm. & 1234 & 1533 & 1619 & 995 & 944 & 2967 & 2430 & 2820 & 3336 & 2710 & 2312 & 2630 & 2127.50 & 25530 & 7.13 \\
\hline \multirow[t]{2}{*}{22} & Stemphylium Wallr. & 205 & 304 & 102 & 78 & 93 & 91 & 121 & 134 & 172 & 187 & 225 & 194 & 158.83 & 1906 & 0.53 \\
\hline & PHYCOMYCOTINA & & & & & & & & & & & & & & & \\
\hline 23 & Cunninghamella Matr. & 934 & 804 & 603 & 697 & 543 & 704 & 398 & 689 & 718 & 614 & 831 & 857 & 699.33 & 8392 & 2.34 \\
\hline 24 & $\begin{array}{c}\text { Phytophthora (Mont) De } \\
\text { Bary }\end{array}$ & 1232 & 1120 & 932 & 844 & 754 & 987 & 567 & 876 & 987 & 776 & 923 & 1157 & 929.58 & 11155 & 3.12 \\
\hline 25 & $\begin{array}{c}\text { Plasmopara Berk and } \\
\text { Curtis. }\end{array}$ & 12 & 26 & 93 & 34 & 78 & 105 & 167 & 224 & 276 & 364 & 238 & 163 & 148.33 & 1780 & 0.50 \\
\hline 26 & Rhizopus Chrenb. & 92 & 107 & 176 & 68 & 45 & 357 & 185 & 123 & 78 & 123 & 113 & 137 & 133.67 & 1604 & 0.45 \\
\hline
\end{tabular}


Table 2. Average month wise contribution of fungal spore groups and meteorological factors during the period of investigation ( $1^{\text {st }}$ January 2018 to $31^{\text {st }}$ December 2018)

\begin{tabular}{|c|c|c|c|c|c|c|c|c|}
\hline \multirow{2}{*}{ Months } & \multicolumn{3}{|c|}{ Fungal spore Groups Average contribution (\%) } & \multicolumn{4}{c|}{ Meteorological factors (Average) } \\
\cline { 2 - 10 } & $\begin{array}{c}\text { Asco } \\
\text { mycotina }\end{array}$ & $\begin{array}{c}\text { Basidio } \\
\text { mycotina }\end{array}$ & $\begin{array}{c}\text { Deutero } \\
\text { mycotina }\end{array}$ & $\begin{array}{c}\text { Phyco } \\
\text { Mycotina }\end{array}$ & $\begin{array}{c}\text { Temp. } \\
(\mathbf{O C})\end{array}$ & $\begin{array}{c}\text { Rainfall } \\
\text { (mm) }\end{array}$ & $\begin{array}{c}\text { Humidity } \\
(\%)\end{array}$ & $\begin{array}{c}\text { Wind speed } \\
\text { (m s-1) }\end{array}$ \\
\hline January & 1.23 & 0.93 & 4.32 & 0.64 & 23 & -- & 32 & 2.41 \\
\hline February & 1.25 & 0.81 & 4.52 & 0.58 & 23 & -- & 28 & 2.19 \\
\hline March & 0.97 & 0.50 & 3.44 & 0.51 & 24 & -- & 30 & 3.11 \\
\hline April & 0.99 & 0.47 & 3.25 & 0.46 & 26 & -- & 32 & 3.47 \\
\hline May & 0.84 & 0.66 & 3.44 & 0.39 & 31 & -- & 28 & 5.11 \\
\hline June & 0.95 & 0.57 & 9.44 & 0.61 & 17 & 74.61 & 72 & 5.12 \\
\hline July & 1.06 & 0.84 & 9.99 & 0.37 & 20 & 138.68 & 82 & 6.83 \\
\hline August & 0.97 & 0.72 & 9.97 & 0.54 & 21 & 73.87 & 85 & 7.86 \\
\hline September & 1.09 & 0.47 & 9.74 & 0.57 & 21 & 29.1 & 78 & 4.11 \\
\hline October & 0.68 & 0.80 & 5.12 & 0.52 & 24 & 2.1 & 46 & 3.44 \\
\hline November & 0.90 & 0.87 & 5.08 & 0.59 & 19 & 5.8 & 42 & 3.69 \\
\hline December & 1.09 & 0.72 & 4.86 & 0.65 & 18 & -- & 30 & 3.5 \\
\hline Total & 12.02 & 8.36 & 73.17 & 6.43 & & & & 21 \\
\hline
\end{tabular}

Table 3. Distribution of fungal spore groups and meteorological parameters for each season during the period of investigation ( $1^{\text {st }}$ January 2018 to $31^{\text {st }}$ December 2018)

\begin{tabular}{|c|c|c|c|c|c|c|c|c|}
\hline Season & \multicolumn{2}{|c|}{ Average fungal spore group contribution (\%) } & \multicolumn{4}{c|}{ Meteorological factors (Average) } \\
\hline & $\begin{array}{c}\text { Asco } \\
\text { mycotina }\end{array}$ & $\begin{array}{c}\text { Basido } \\
\text { mycotina }\end{array}$ & $\begin{array}{c}\text { Deutero } \\
\text { mycotina }\end{array}$ & $\begin{array}{c}\text { Phyco } \\
\text { mycotina }\end{array}$ & $\begin{array}{c}\text { Temp. } \\
\left(\mathbf{(}^{\mathbf{C}}\right)\end{array}$ & $\begin{array}{c}\text { Rainfall } \\
(\mathbf{m m})\end{array}$ & $\begin{array}{c}\text { Humidity (\%) } \\
\text { Wind speed } \\
\left(\mathbf{m ~ s}^{-1}\right)\end{array}$ \\
\hline Summer & 1.01 & 0.61 & 3.66 & 0.49 & 26 & -- & 29.5 & 3.47 \\
\hline Monsoon & 1.02 & 0.65 & 9.79 & 0.52 & 19.75 & 79.07 & 79.25 & 5.98 \\
\hline Winter & 0.98 & 0.83 & 4.85 & 0.6 & 21 & 3.95 & 37.5 & 3.26 \\
\hline
\end{tabular}

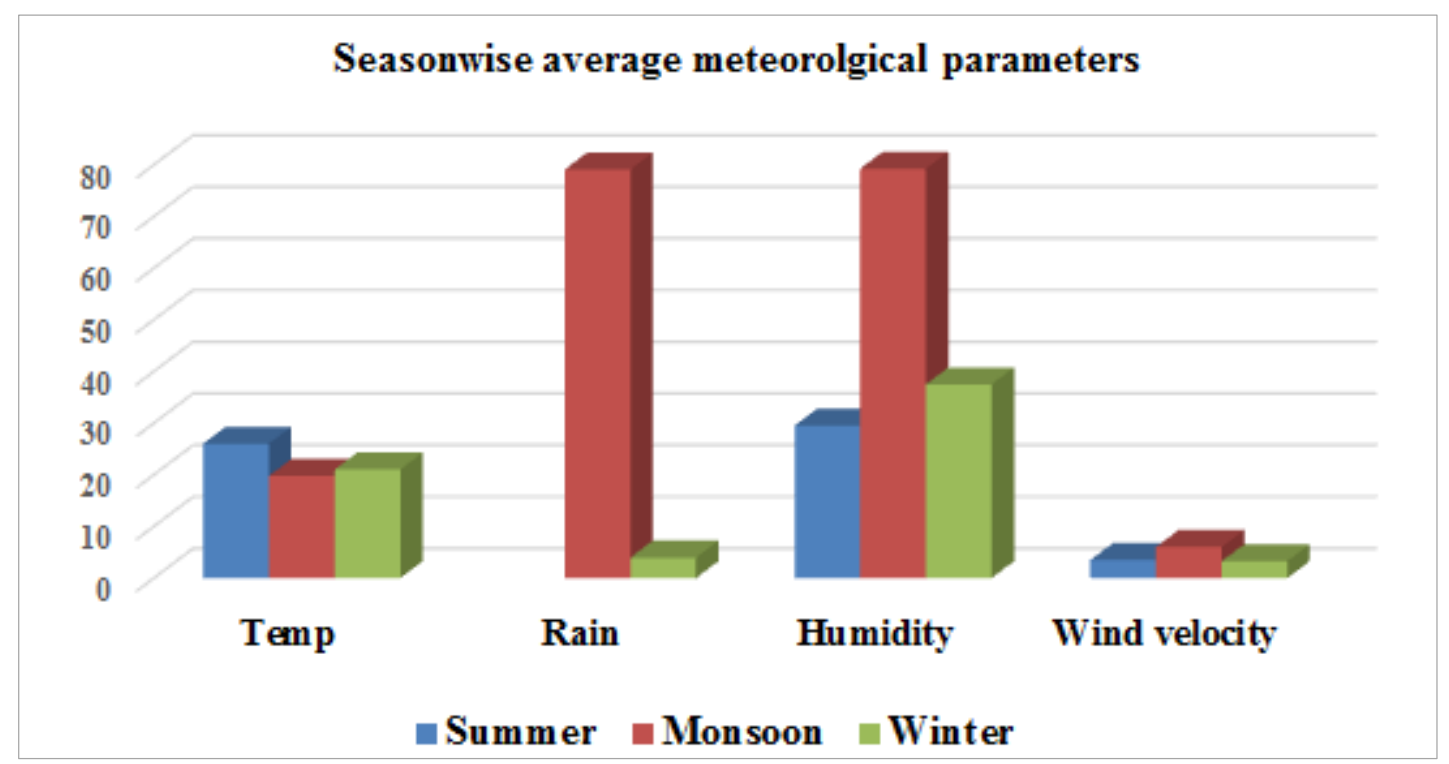

Figure 1. Season wise average meteorological parameters 

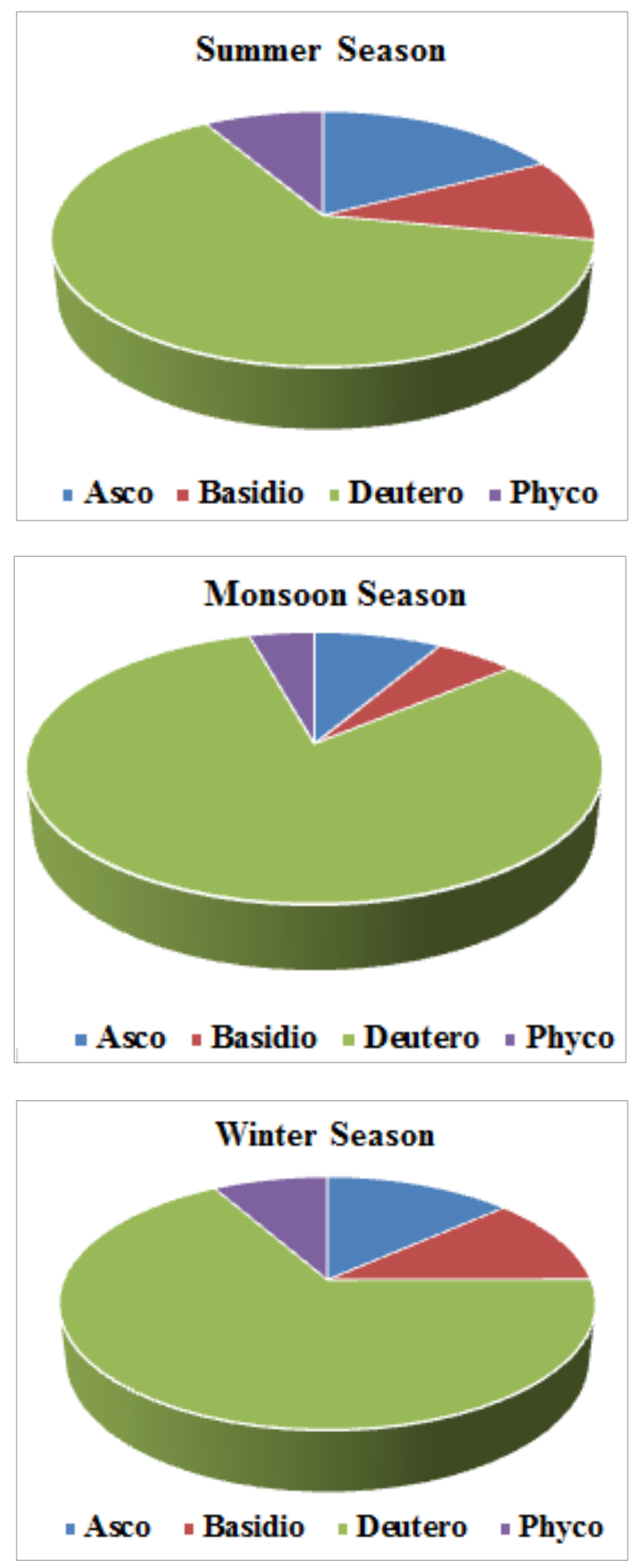

Figure 2. Season wise average percentage contribution of fungal spore groups during the Period of investigation $\left(1^{\text {st }}\right.$ January 2018 to $31^{\text {st }}$ December 2018)

The spore load was found to be comparatively less in monsoon season (except in case of Deuteromycotina) than that of winter and summer season. In winter season; spore load increases slightly, especially in case of Deuteromycotina i.e. maximum of $5.12 \%$ with an average contribution of $4.85 \%$ to the total airspora. (Table $2 \&$ Table 3). This may be due to moderate temperature (average $21^{\circ} \mathrm{C}$ ) with adequate amount of relative humidity. (Weber; 2003). The sporulation in different fungal genera are influenced in varied manner due to various climatic factors like temperature, moisture content and precipitation as observed in case of spore belonging to Ascomycotina and Deuteromycotina. Though the spore discharge and dispersal is enhanced by dry air with high wind velocity; the spores like Curvularia, Nigrospora showed increase in their concentration with the increase in moisture content associated with slight decrease in temperature. Such observations are supported by earlier reports of Chakrabarti et al. (2012). Discharge of fungal spores may be stimulated by precipitation that was observed in case of Ascomycotina, Basidiomycotina and Deuteromycotina; the spores show significant increase with an increase in relative humidity and rainfall in monsoon season; same findings have been recorded previously by Gregory (1973); Roy et al. (2017). The spores like Aspergillus is also found to be highest during the monsoon season followed by winter and summer seasons. Oberle, M. et al. (2015); Gunthe et al. (2017). It was observed that the months with high relative humidity and rainfall witnessed significant increase in fungal spore collection throughout the period of sampling. The occurrence of spores like Cladosporium, Alternaria was rarely found to be associated with high temperature values unlike it was observed in the study of Grinn-Gofron and Bosiacka (2015), Grinn-Gofron et al. (2018). A gradual increase has been observed in collection of some fungal spore types during the months of January, February, and June; especially in case of spores like Alternaria and Fusarium; these were found to be highest in the month of June as observed by Odebode A. et al. (2020). Also, fungal spores like Fusarium oxysporum in association with root knot nematode is found to be a cause for wilt disease on young guava trees. Singh (2020). Similarly, Colletotrichum gloeosporoides is also responsible for Anthracnose disease. Shinde and Ahire (2017); Shinde (2020). Similarly; Smuts spores are found to be showing positive correlation with the wind velocity and their blowing away (deflation) occurred easily as pointed by Gregory (1961). Among the Deuteromycotina; though the spore load was found highest with its maxima of $9.99 \%$ in monsoon and $5.12 \%$ in winter season and was recorded minimum during summer season $(3.25 \%)$; the fungal spores like Fusarium, Cladosporium, and Phytophthora which are known pathogens and causal agents for most of fungal diseases in guava; these have been found to occur more in number at low temperatures during winter season as compared to summer and monsoon season. Fusarium was found to be one of the dominant fungal spore in monsoon seasons. Sri Harsha Kota et al. (2018). This observation is slightly divergent to the earlier findings of Pitt; (1979), Pitt and Hocking (2009).

In case of Ascomycotina; the spore load was recorded sufficiently high i.e. $1.01 \%$ with average maximum of $1.25 \%$ during the summer season when there is no precipitation, low humidity $(29.5 \%)$ with moderate wind velocity $\left(3.47 \mathrm{~ms}^{-1}\right)$. (Table $2 \&$ Table 3$)$. However; the 
Ascospores like Didymosphaeria, Lophiostoma and Pringshemia, Lacanidion and Hypoxylon were found to occur more during low temperatures and high moisture periods in the months of monsoon and winter season and that was partially agreed with previous findings of Kulkarni (1971). Likewise, the Ascospore types like Pleospora, and Sporormia were present in the dry period and mainly occurred during increase in relative humidity with decreased temperature in winter season. (Table 1). The present study revealed that, the rainfall is having its immediate impact on the spore release of Ascomycotina, also; the temperature and rainfall are the two external factors which greatly affects the development of reproductive structures. Bauer (2008); Ball and Ketterson (2008). Many of the fungal spores have been found to occur throughout the period of investigation and this could be due to agricultural run-off through irrigation of the neighbouring crop fields.

The spore load of Phycomycotina was found to be in the range of $0.37 \%$ to $0.65 \%$ during the months of monsoon and winter seasons as seen in case of Rhizopus temperature between $19^{\circ} \mathrm{C}$ to $21^{\circ} \mathrm{C}$ and high percentage of humidity (79.25\%) favours discharge and dispersal of conidiophores and spores that is facilitated by rainfall and high percentage of relative humidity. (Table 2). Also, the average size of the spores is comparatively larger, which helps in quick settlement of the spores. As the germination of spores is stimulated by first showers of rain; the concentration of spores was found to be higher during the months of June However; during the month of July and early August the spore concentration was found to be less; that might be due to the heavy rainfall and rapid deposition of spores on the growing vegetation and the soil surface. Shinde and Ahire (2017).

It has been well established that the changes in the climate especially in temperature and annual rainfall have a significant influence on the timing, duration and intensity of sporadic outbreak. Boddy et al. (2014); Pakpour et al. (2015); Jana Scevkova et al. (2016). The fungal spores such as Alternaria, Aspergillus, Cladosporium, Curvularia, Helminthosporium, Nigrospora, Cercospora, Colletotrichum, Fusarium etc. were found to occur with their high concentration when high precipitation (average $79.07 \mathrm{~mm}$ ) and slight decrease in the average daily temperature $\left(19.75^{\circ} \mathrm{C}\right)$ with high percentage of humidity $(79.25 \%)$ as recorded during the months of monsoon season like of July, August, and September. (Table 2). Also, the fungal spore types like Epicoccum and Stemphylium are found to occur in high concentration during the late winter season when the climate is quite warm, dry and sunny. Timmer et al. (1998).

Increased temperatures (mean, maximum or minimum) may enhance the amount of spores in the atmosphere may induce longer spore seasons and advance sporulation time of fungi Reyes et al. (2009); De Linares et al. (2010). In the recent years; many megacities like Nasik have experiencing fluctuations in the daily average temperature; and a development of a specific microclimate and high proportion of build-up areas Alabi (2012). The changes in daily average temperature can affect the production, release and dispersion of fungal spores in the air. Hollins et al. (2004).

Analysis of the two-way ANOVA for average contribution of fungal spore groups and meteorological parameters in three seasons showed no significant difference in between average contribution fungal spore groups over the different seasons and changing climatic conditions during the study period. (Table 4). The differences were observed with respect to the changing meteorological parameters and fungal spore concentrations of individual spore types as well as spores groups with average monthly concentrations, but no statistically significant difference was observed when the overall total average percent contributions of spore groups were considered. The possible reason might be the insignificant changes of environmental factors as well as the fungal growth substrates at the sampling site during the one-year sampling. (Pawan and Manjunath; 2014).

The results of fungal spore occurrence and the associated changing meteorological parameters particularly for guava fruit crop of Nasik region may provide useful input for the study of airborne, plant pathogenic fungal airspora. However; the findings may vary according to the vegetation types, fungal growth patterns, sampler used, sampling techniques etc. hence these may not be generalized for the other such locations.

Table 4. Two way ANOVA for fungal spore group and meteorological parameters

\begin{tabular}{|l|c|c|c|c|c|c|}
\hline Source of Variation & Sum of Squares (SS) & $\begin{array}{c}\text { Degrees of } \\
\text { freedom(df) }\end{array}$ & $\begin{array}{c}\text { Mean } \\
\text { Squares(MS) }\end{array}$ & F Value & P-value & F crit \\
\hline Spore groups & 1080.994314 & 1 & 1080.99431 & 2.46732336 & 0.167291 & 5.987377607 \\
\hline Seasons & 6151.227271 & 6 & 1025.20455 & 2.339985595 & 0.16229 & 4.283865714 \\
\hline Error & 2628.745786 & 6 & 438.124298 & & & \\
\hline & & & & & & \\
\hline Total Variation & 9860.967371 & 13 & & & & \\
\hline
\end{tabular}




\section{REFERENCES}

[1] Adeyinka Odebode, Adedotun Adekunle, Jason Stajich and Peter Adeonipekun (2020). Airborne fungi spores distribution in various locations in Lagos, Nigeria, Environ. Monit. Assess., Springer, 192:87 1-14.

[2] Agnieszka Grinn-Gofron and Beata Bosiacka (2015). Effects of meteorological factors on the composition of selected fungal spores in the air. Aerobiologia 31: 63-72.

[3] Agnieszka Grinn-Gofron, Beata Bosiacka, Aleksandra Bednarz Tomasz Wolski (2018). A comparative study of hourly and daily relationships between selected meteorological parameters and airborne fungal spore composition. Aerobiologia 34: 45-54.

[4] Alabi, M. O. (2012). The built up environment and micro-climate variation in Lokoja, Nigeria. American International Journal of Contemporary Research, 12, $150-158$.

[5] Azcón-Bieito, J., \& Talón, M. (2000). Fundamentos de fisiologia vegetal. Madrid: McGraw Hill.

[6] Boddy, L., Büntgen, U., Egli, S., Gange, A. C., Heegaard, E., Mirk, P. M., et al. (2014). Climate variation effects on fungal fruiting. Fungal Ecology 10, 20-33.

[7] Chakrabarti, H. S., Das. S. and Gupta-Bhattacharya, S. (2012). Outdoor airborne fungal spora load in a suburb of Kolkata, India: its variation, meteorological determinants and health impact. Int. J. Environ. Health Res. 22:37-50.

[8] Charlotte Sindt Jean-Pierre Besancenot and Michel Thibaudon (2016). Airborne Cladosporium fungal spores and climate change in France. Aerobiologia Vol. 32, Issue 1, pp 53-68.

[9] Davide Sardella, Arianne Muscat, Jean-Pierre Brincat, Ruben Gatt, Stephen Decelis \& Vasilis Valdramidis (2016). A comprehensive review of the pear fungal diseases. International Journal of Fruit Science 1-27. ISSN: 1553-8362 (Print) 1553-8621 (Online).

[10] De Linares, C., Belmonte, J., Canela, M., de la Gauardia, C. D., Alba-Sanchez, F., Sabariego, S., \& Alonso-Pérez, S. (2010). Dispersal patterns of Alternaria conidia in Spain. Agricultural and Forest Meteorology, 150, 1491-1500.

[11] Fischer, I.H. Ana Raquel Soares-Colletti, Maria Cecilia de Arruda, Marise C.M.P. Amorim, L. (2017). Temporal progress and spatial patterns of quiescent diseases in Guava influenced by sanitation practices. Scientia Agricola Vol.74 No.1 68-76.

[12] Gregory, P. H. (1961). The microbiology of the atmosphere, London, L. Hill.

[13] Gregory, P. H. (1973). The microbiology of atmosphere. Bucks, Leonard Hill, London: Aylesbury.

[14] Gupta, V.K., Mishra, A. K., Gaur, R. K. (2010). Current status of Fusarium wilt disease of Guava (Psidium guajava L. in India, Biotechnology 9 (2):176-195, ISSN 1682-296X.

[15] Hema Priyamvada, Raj Kamal Singh, M. Akila, R.
Ravikrishna, Rama Shanker Verma \& Sachin S. Gunthe (2017) Seasonal variation of the dominant allergenic fungal aerosols: One year study from southern Indian region. Scientific Reports, Springer Nature 7: 1-12.

[16] Hirst, J. M. (1952). An Automatic volumetric spore trap. Ann. appl. Biol. 39:257-265.

[17] Hollins, P. D., Kettlewell, P. S., Atkinson, M. D., Stephenson, D. B., Corden, J. M., Millington, W. M., et al. (2004). Relationships between airborne fungal spore concentration of Cladosporium and summer climate at two sites in Britain. International Journal of Biometeorology, 48, $137-141$.

[18] Jana S cevkova, Jozef Dusicka, Karol Micieta, Jan Somorckk (2016). The effects of recent changes in air temperature on trends in airborne Alternaria, Epicoccum and Stemphylium spore seasons in Bratislava (Slovakia). Aerobiologia $32: 69-81$

[19] Kumar A, Attri A.K. (2016). Characterization of fungal spores in ambient particulate matter: a study from the Himalayan region. Atmos Environ. 142: 182-193.

[20] Mishra, J. K. and Deshmukh, S. K. (2009). Fungi from different environments. Science Publishers U.S.A. ISBN: 978-1-57808-578-1.

[21] Mohture, V.M., Korpenwar, A.N. (2015). Airborne fungal diversity of Nagbhid (M.S.) India Int. Journ. Appl. Res. ISSN 2394-7500. 116-118.

[22] Neetu Singh (2020). Emerging problem of guava decline caused by Meloidogyne enterolobii and Fusarium oxysporum F.sp.psidii. Indian Phytopathology Springer, 1-2.

[23] Oberle, M. et al. (2015). Non-seasonal variation of airborne Aspergillus spore concentration in a hospital building. Int. J. Environ. Res. Public Health 12, 13730-13738.

[24] Pakpour, S., Li, D. W., \& Klironomos, J. (2015). Relationships of fungal spore concentrations in the air and meteorological factors. Fungal Ecology, 13, 130-134.

[25] Pitt, J. I., and A. D. Hocking. (2009). Spoilage of stored, processed and preserved foods, p. 401-421. Fungi and food spoilage. Springer, New York.

[26] Pitt, J.I. (1979). The genus Penicillium and its teleomorphic states Eupenicillium and talaromyces. Mycologia 73(3): $582-584$.

[27] R. Pavan and K. Manjunath (2014). Qualitative analysis of indoor and outdoor airborne fungi in cowshed. Journal of Mycology, Hindawi Publishing Corporation, Volume 20 (14), 1-14.

[28] Rajyalakshmi Garaga, C. K. R. Avinash \& Sri Harsha Kota (2018). Seasonal variation of airborne allergenic fungal spores in ambient $\mathrm{PM}_{10}$ - a study in Guwahati, the largest city of north-east India. Air Quality, Atmosphere \& Health, Springer. 1-10.

[29] Sánches Reyes, E., Rodríguez de la Cruz, D., Sanchís Merion, M. E., \& Sánchez Sánchez, J. (2009). Meteorological and agricultural effects on airborne Alternaria and Cladosporium spores and clinical aspects in Valladolid (Spain). Annals of Agricultural and Environmental Medicine, 16, 53-61. 
[30] Shinde, H.P. (2020). Studies on some pathogenic fungal spores and disease incidence over guava fruit orchard at Nasik, M.S., Plant Archives, Vol. 20, Supplement 1, pp. 2613-2617 e-ISSN:2581-6063 (online), ISSN: 0972-5210.

[31] Shinde, H.P. and Ahire, P.P. (2017). Prevalence of fungal spores belonging to Deuteromycotina over Guava (Psidium guajava linn.) orchard in Nashik, Maharashtra, India. Plant Archives Vol. 17 No. 1, pp. 55-58 ISSN 0972-5210.

[32] Shipra Roy, Arindom Chakraborty, Saibal Maitra and Kashinath Bhattacharya (2017). Monitoring of airborne fungal spore load in relation to meteorological factors, air pollutants and allergic symptoms in Farakka, an unexplored biozone of eastern India. Environ Monit. Assess. 189 (370). 1-14. Springer International Publishing Switzerland.

[33] Sumra Naseer, Shabbir Hussain, Naureen Naeem, Muhammad Parvaiz, and Madiha Rahman (2018). The phytochemistry and medicinal value of Psidium guajava (guava). Clinical phytoscience. 4 (32).1-8.
[34] Surendranathan K.K. (2005). Post-harvest biotechnology of fruits with special reference to banana-Perspective and Scope Indian J. Biotech. 4, 39-46.

[35] Tilak, S. T. and Kulkarni, R. L. (1970). A new air sampler. Experentia. 25:443-444.

[36] Timmer, L. W., Solel, Z., Gottwald, T. R., Ibanez, A. M., and Zitko, S. E. (1998). Environmental factors affecting production, release, and field populations of conidia of Alternaria alternata, the cause of brown spot of citrus. Phytopathology, 88, 1218-1223.

[37] Weber, R. W. (2003). Meteorological variables in aerobiology. Immunology and Allergy Clinics of North America, 23, 411-422.

[38] Zhu S.J. (2006). Non-chemical approaches to decay control in postharvest fruit, Advances in Postharvest technologies for Horticultural Crops, Eds. B. Noureddine, B. and S. Norio, Research Signpost, Trivandrum, India, 297-313. 